\title{
With Great Hopes Come Great Expectations: Access and Adoption Issues Associated With COVID-19 Vaccines
}

Zhaohui $\mathrm{Su}^{1}$, MA, PhD; Dean McDonnell ${ }^{2}, \mathrm{PhD}$; Ali Cheshmehzangi ${ }^{3,4}, \mathrm{PhD}$; Xiaoshan $\mathrm{Li}^{5}, \mathrm{PhD}$; Daniel Maestro ${ }^{6}$, $\mathrm{PhD}$; Sabina Šegalo ${ }^{7}, \mathrm{PhD}$; Junaid $\mathrm{Ahmad}^{8}, \mathrm{PhD}$; Xiaoning $\mathrm{Hao}^{9}, \mathrm{PhD}$

${ }^{1}$ Center on Smart and Connected Health Technologies, Mays Cancer Center, School of Nursing, UT Health San Antonio, San Antonio, TX, United States

${ }^{2}$ Department of Humanities, Institute of Technology Carlow, Carlow, Ireland

${ }^{3}$ Department of Architecture and Built Environment, University of Nottingham Ningbo China, Ningbo, China

${ }^{4}$ Hiroshima University, Hiroshima, Japan

${ }^{5}$ Program of Public Relations and Advertising, Beijing Normal University-Hong Kong Baptist University United International College, Zhuhai, China

${ }^{6}$ Department of Environmental Health, Institute for Public Health of Federation Bosnia and Herzegovina, Sarajevo, Bosnia and Herzegovina

${ }^{7}$ Department of Microbiology, Faculty of Medicine, University of Sarajevo, Sarajevo, Bosnia and Herzegovina

${ }^{8}$ Prime Institute of Public Health, Peshawar Medical College, Peshawar, Pakistan

${ }^{9}$ Division of Health Security Research, China National Health Development Research Center, National Health Commission, P.R. China, Beijing, China

Corresponding Author:

Xiaoning Hao, PhD

Division of Health Security Research, China National Health Development Research Center, National Health Commission, P.R. China

No. 9 Chegongzhuang Street, Xicheng District

Beijing, 100044

China

Phone: 8601088385748

Email: haoxn@nhei.cn

\section{Abstract}

Although COVID-19 vaccines are becoming increasingly available, their ability to effectively control and contain the spread of the COVID-19 pandemic is highly contingent on an array of factors. This paper discusses how limitations to vaccine accessibility, issues associated with vaccine side effects, concerns regarding vaccine efficacy, along with the persistent prevalence of vaccine hesitancy among the public, including health care professionals, might impact the potential of COVID-19 vaccines to curb the pandemic. We draw insights from the literature to identify practical solutions that could boost people's adoption of COVID-19 vaccines and their accessibility. We conclude with a discussion on health experts' and government officials' moral and ethical responsibilities to the public, even in light of the urgency to adopt and endorse "the greatest amount of good for the greatest number" utilitarian philosophy in controlling and managing the spread of COVID-19.

(JMIR Public Health Surveill 2021;7(8):e26111) doi: $10.2196 / 26111$

\section{KEYWORDS}

COVID-19; coronavirus; COVID-19 vaccine; made in China; vaccine efficacy; vaccine safety; vaccine; China; expectation; safety; efficacy; infectious disease; public health; consequence; public health; standard

\section{Background}

How would we as a society remember COVID-19 after the postpandemic realities become the new normal? The destruction it caused, or the construction it motivated? The fears it inflamed, or the hopes it inspired? The transmission it kindled, or the determination it fanned? The sickness it roused, or the human solidarity it helped cement? As COVID-19 is still evolving, it might be difficult to determine how the pandemic might fold or the contours of the finale. What is clear, though, is that COVID-19 vaccines have already forged and will continue to shape society's collective memories of the great pandemic of the 21 st century - the almost-stopped-the-world-go-round global crisis that the COVID-19 pandemic is [1-3]. As of May 24, 2021, COVID-19 has already claimed 167 million infections and 3.46 million deaths [1]—numbers that might only represent a fraction of the true toll, as indicated by investigations led by 
the World Health Organization (WHO) and other organizations (eg, the Economist) [2,3]. Although the pandemic has upended the lives and livelihoods of thousands of millions of families and has dragged the world economy into unknown terrain [4], COVID-19 vaccines offer rays of hope that continue to draw people closer to the end of the tunnel [5].

Determined to build some "normalcy," a global race to develop vaccines that can halt the pandemic has elevated on decades of experience and knowledge on immunization, the most advanced establishment of infrastructure, and an unwavering talent and motivation united to curb the spread of the virus [6,7]. Starting from December 2020, nine months after the WHO first labeled COVID-19 a global pandemic [8], the United Kingdom became the first nation to roll out mass vaccination [9]. Owing to its success in administering shots at the arms, as of May 2021, after months of strict social distancing mandates and within the confines of certain rules, UK residents have once again been able to enjoy shots at pubs indoors [10], with the company of strangers, friends, or one's inner peace. COVID-19 vaccines, essentially, are the shots of hope people have been anxiously waiting for; when human contact is no longer as contagious as it used to be, hugs, handshakes, and heart-shaped selfies will become possible again across the world. Not to mention the happiness experienced when reuniting with families through nursing home visits, rekindling friendships with face-to-face lectures, and the bittersweet dash to a closing gate for business and leisure travel.

However, it is important to note that COVID-19 vaccines are not equally distributed silver bullets. How well COVID-19 vaccines can help curb the pandemic is contingent upon factors ranging from vaccine accessibility and vaccine efficacy to vaccine hesitancy, particularly in light of uncertainties associated with COVID-19 mutations [11-15]. Not much is discussed about critical issues associated with COVID-19 vaccine access and adoption while sharing positive news on COVID-19 vaccines and during talks about recovery and normalcy. Therefore, in this paper, we examine key factors that shape people's access to and adoption of COVID-19 vaccines. Furthermore, we draw insights from the literature and aim to identify strategies that could boost people's adoption of and the availability of COVID-19 vaccines, and ethical considerations associated with these strategies.

\section{Issues Associated With Vaccine Inequity and Accessibility}

It is important to note that vaccine availability does not equate to vaccine accessibility [11]. As a result of limitations in vaccine production, although more COVID-19 vaccines will become available in the coming months, not all people will have the same level of access. In the United Kingdom, for instance, older adults and frontline workers (eg, health care professionals) will be vaccinated first [16]. Simultaneously, in the United States, vaccine distribution policy will be heavily influenced by federal and state policies [17]. In addition to the prioritized distribution of vaccines, trial data availability also affects COVID-19 vaccine accessibility to individual end-users. For example, although expectant mothers are susceptible to COVID-19 [18], most vaccines were not tested on pregnant or lactating women; these individuals will not have access to COVID-19 vaccines until data become available [19]. In other words, although COVID-19 vaccines are available to use, they are not available to use for everyone [19]. This revelation speaks volumes-even though women have been historically ignored and underrepresented in clinical trials [20], it is difficult to contemplate that the same gender inequality could occur amid a pandemic of COVID-19's scale.

Equally disturbing, evidence further suggests that $90 \%$ of people living in 70 poor-income countries across the world will not have access to COVID-19 mass immunization campaigns until 2022 or 2023 [21,22], with the worst estimate pointing to 2024 [23]. On the other hand, high-income countries are hoarding vaccines; by early December 2020, Canada, for instance, had ordered enough doses of COVID-19 vaccines to inoculate each Canadian five times [24]. Overall, as of May 21, 2021, wealthy countries such as the United States, the United Kingdom, Australia, and other nations within the European Union (EU), have collectively ordered approximately 7.8 billion doses of COVID-19 vaccines, whereas only $270,200,000$ vaccines are available for low-income countries [23].

COVID-19 vaccines often require advanced infrastructure for storage and delivery (see Table 1) [25]. For instance, to safeguard their potency, Pfizer-BioNTech vaccines are required to be stored and transported between $-112^{\circ} \mathrm{F}$ and $76^{\circ} \mathrm{F}\left(-80^{\circ} \mathrm{C}\right.$ to $-60^{\circ} \mathrm{C}$ ) [26]; this condition can only be achieved with advanced cold chain systems that are difficult to build and navigate $[27,28]$. In the United States, due to a failure in storage, a company responsible for vials of the Moderna vaccine, which must be kept cold, spoiled 890 doses destined for older adults in eight nursing home residents in Ohio [29]. At least in the United States, even though several states are not sharing their data, available evidence already shows that vaccine waste is prevalent across states [15]. Considering how higher-income countries face logistical issues using state-of-the-art and high-capacity cold chain systems [28], it is difficult to imagine how low- and middle-income countries will gain access to these vaccines, and how will they deliver these vials to their citizens. Furthermore, pressing issues such as accessibility of glass vials, syringes, and needles may further worsen the COVID-19 accessibility conundrum [28,30]. 
Table 1. Details of leading COVID-19 vaccines with known efficacy (as of June 2, 2021).

\begin{tabular}{|c|c|c|c|c|c|c|}
\hline Name & Developer & Country & Type & Efficacy (Dose) & Status & Storage \\
\hline $\begin{array}{l}\text { Convidecia (or Ad5- } \\
\mathrm{nCoV} \text { ) }\end{array}$ & CanSino & China & Adenovirus & $\begin{array}{l}65.28 \% \text { (single } \\
\text { dose) }\end{array}$ & $\begin{array}{l}\text { Approved in China, } \\
\text { emergency use in Chile, } \\
\text { Hungary, Pakistan, etc }\end{array}$ & $\begin{array}{l}\text { Stable in regular refrigerator } \\
\text { for at least } 6 \text { months }\end{array}$ \\
\hline BBIBP-CorV & Sinopharm & China & Inactivated & $\begin{array}{l}86 \% \text { ( } 2 \text { doses, } 3 \\
\text { weeks apart) }\end{array}$ & $\begin{array}{l}\text { Approved in } \mathrm{UAE}^{\mathrm{a}} \text { and } \\
\text { Bahrain; emergency use } \\
\text { in Egypt and Jordan }\end{array}$ & $\begin{array}{l}\text { Stable in regular refrigerator } \\
\text { for at least } 6 \text { months }\end{array}$ \\
\hline$\underline{-}^{\mathrm{b}}$ & $\begin{array}{l}\text { Sinopharm- } \\
\text { Wuhan }\end{array}$ & China & Inactivated & $72.8 \%$ & $\begin{array}{l}\text { Limited use in China and } \\
\text { UAE }\end{array}$ & $\begin{array}{l}\text { Stable in regular refrigerator } \\
\text { for at least } 6 \text { months }\end{array}$ \\
\hline $\begin{array}{l}\text { CoronaVac (former- } \\
\text { ly PiCoVacc) }\end{array}$ & Sinovac & China & Inactivated & $\begin{array}{l}50.38 \%-78 \%(2 \\
\text { doses, } 2 \text { weeks } \\
\text { apart })\end{array}$ & $\begin{array}{l}\text { Limited use in China, } \\
\text { Brazil, etc }\end{array}$ & $\begin{array}{l}\text { Stable in regular refrigerator } \\
\text { for at least } 6 \text { months }\end{array}$ \\
\hline $\begin{array}{l}\text { Covaxin (or } \\
\text { BBV152 A, B, C) }\end{array}$ & $\begin{array}{l}\text { Bharat } \\
\text { Biotech }\end{array}$ & India & Inactivated & $\begin{array}{l}78 \% \text { ( } 2 \text { doses, } 4 \\
\text { weeks apart) }\end{array}$ & $\begin{array}{l}\text { Emergency use in India, } \\
\text { Philippines, Zimbabwe, } \\
\text { etc }\end{array}$ & $\begin{array}{l}\text { At least a week at room } \\
\text { temperature }\end{array}$ \\
\hline Sputnik V & Gamaleya & Russia & Adenovirus & $\begin{array}{l}91.4 \% \text { ( } 2 \text { doses, } \\
3 \text { weeks apart) }\end{array}$ & Early use in Russia & Freezer storage \\
\hline EpiVacCorona & $\begin{array}{l}\text { Vector Insti- } \\
\text { tute }\end{array}$ & Russia & Protein & $\begin{array}{l}\text { - }(2 \text { doses, } 3 \\
\text { weeks apart })\end{array}$ & $\begin{array}{l}\text { Limited use in Russia } \\
\text { and Turkmenistan }\end{array}$ & $\begin{array}{l}\text { Stable in refrigerator for up } \\
\text { to } 2 \text { years }\end{array}$ \\
\hline $\begin{array}{l}\text { Vaxzevria (or } \\
\text { AZD1222/Cov- } \\
\text { ishield) }\end{array}$ & $\begin{array}{l}\text { Oxford-As- } \\
\text { traZeneca }\end{array}$ & $\begin{array}{l}\mathrm{UK}^{\mathrm{c}} \text { and } \\
\text { Sweden }\end{array}$ & Adenovirus & $\begin{array}{l}60 \%-90 \% \text { ( } 2 \text { dos- } \\
\text { es, } 4 \text { weeks apart) }\end{array}$ & $\begin{array}{l}\text { Stopped use in Denmark } \\
\text { and Norway; emergency } \\
\text { use in UK, Lebanon, } \\
\text { Canada, etc }\end{array}$ & $\begin{array}{l}\text { Stable in regular refrigerator } \\
\text { for at least } 6 \text { months }\end{array}$ \\
\hline Ad26.COV2.S & $\begin{array}{l}\text { Johnson \& } \\
\text { Johnson }\end{array}$ & $\mathrm{US}^{\mathrm{d}}$ & Adenovirus & $\begin{array}{l}57 \%-72 \%(1 \\
\text { dose })\end{array}$ & $\begin{array}{l}\text { Stopped use in Denmark } \\
\text { and Finland; emergency } \\
\text { use in US, the European } \\
\text { Union, etc }\end{array}$ & $\begin{array}{l}\text { Up to } 2 \text { years at }-4^{\circ} \mathrm{F} \\
\left(-20^{\circ} \mathrm{C}\right) \text { or up to } 3 \text { months } \\
\text { at } 36-46^{\circ} \mathrm{F}\left(2-8^{\circ} \mathrm{C}\right)\end{array}$ \\
\hline mRNA-1273 & Moderna & US & mRNA & $\begin{array}{l}94.5 \% \text { ( } 2 \text { doses, } \\
4 \text { weeks apart) }\end{array}$ & $\begin{array}{l}\text { Approved in Canada; } \\
\text { emergency use in US, } \\
\text { UK, etc }\end{array}$ & $\begin{array}{l}\text { Stable in refrigerator for up } \\
\text { to } 30 \text { days }\end{array}$ \\
\hline NVX-CoV2373 & Novavax & US & Protein & $\begin{array}{l}49.4 \%-89.3 \%(2 \\
\text { doses, } 3 \text { weeks } \\
\text { apart) }\end{array}$ & - & $\begin{array}{l}\text { Stable in regular refrigerator } \\
\text { for at least } 6 \text { months }\end{array}$ \\
\hline $\begin{array}{l}\text { Tozinameran or } \\
\text { Comirnaty or } \\
\text { BNT162b2 }\end{array}$ & $\begin{array}{l}\text { Pfizer-BioN- } \\
\text { Tech }\end{array}$ & $\begin{array}{l}\text { US and Ger- } \\
\text { many }\end{array}$ & mRNA & $\begin{array}{l}95 \% \text { ( } 2 \text { doses, } 3 \\
\text { weeks apart) }\end{array}$ & $\begin{array}{l}\text { Approved in Canada, } \\
\text { Saudi Arabia, UAE, } \\
\text { Bahrain, and Kuwait; } \\
\text { emergency use in UK, } \\
\text { US, etc }\end{array}$ & $\begin{array}{l}\text { Freezer storage only at } \\
-94^{\circ} \mathrm{F}\left(-70^{\circ} \mathrm{C}\right)\end{array}$ \\
\hline
\end{tabular}

${ }^{\mathrm{a} U A E}$ : United Arab Emirates.

${ }^{\mathrm{b}}$ Not available.

${ }^{\mathrm{c}}$ US: United States.

${ }^{\mathrm{d}} \mathrm{UK}$ : United Kingdom.

\section{Issues Associated With COVID-19 Vaccine Safety and Vaccine Hesitancy}

Assuming everything goes as planned, COVID-19 vaccine efficacy will still be contingent upon the abilities of individual health facilities to administer their doses. Emerging concerns point to the fact that these institutions often vary in terms of safety protocols, equipment maintenance, and staff training-critical competency criteria that could impact the vaccine administration process, and in turn, vaccine efficacy $[17,31]$. Competency of vaccine distribution centers also impacts end-user safety. For instance, in the state of West Virginia, 42 people who were scheduled to receive COVID-19 vaccines were mistakenly injected with an experimental monoclonal antibody treatment that should be administered via an intravenous infusion [32]. In reality, hospitals and medical centers across the world are overstretched and are at a breaking point in addressing the skyrocketing COVID-19 cases [33-36]; many further compound the moral (eg, who should receive COVID-19 vaccines?) and logistical (eg, how to administer these vaccines effectively and safely?) issues associated with vaccine administration.

After severe allergic reaction cases were first reported in the United Kingdom, regulators warned that Pfizer-BioNTech vaccine administration should not be carried out on people with a history of serious allergies [37]. It is worth noting that these 
reports occurred prior to the incidents of blood clots reported across the globe, especially in the EU nations [38]. The ever-emerging reports on COVID-19 vaccine side effects are alarming [39-41], as some individuals may not be aware of their allergies or underlying conditions that could expose them to severe vaccine side effects [11]. When they do, vaccine distribution facilities will have to face medical emergencies that they may or may not be capable of tackling. For the Pfizer-BioNTech vaccine trial alone, four volunteers developed Bell palsy or partial facial paralysis during the trial period [42]. For most established vaccines, such as seasonal influenza vaccines, allergic reactions often occur at a low rate estimated at one in a million people [43]; this number is substantially lower number compared to the current known allergic cases associated with COVID-19 vaccines, which is 11.1 per million people for the Pfizer-BioNTech COVID-19 vaccine [44].

In Norway, 23 older adults died shortly after COVID-19 vaccination [45]. Although the investigation is still underway, reports on vaccine side effects, especially if taken out of context, be it by legacy media outlets or conspiracy theory influencers, may further deepen the public's fear, uncertainty, and distrust over COVID-19 vaccines [46]. Not to mention the tsunami of fact-based reports or how fake news may further exacerbate the public's pandemic fatigue, along with potential mental health issues [47-49]. Inevitably, concerns associated with vaccine safety and reports on vaccine side effects may further hinder COVID-19 vaccine adoption [50-53], especially among those who spread unfounded vaccine rumors (eg, vaccine conspirators) or those who are already hesitant about COVID-19 vaccine uptake (eg, vaccine hesitants) [12]. Emerging reports on the impacts of COVID-19 mutations on vaccine efficacy may further compound the situation. Trial data on the Johnson \& Johnson vaccines, for instance, show that although the vaccine efficacy is $72 \%$ in the United States, it dropped significantly in places where COVID-19 mutations are more prevalent-66\% in Latin America and 57\% in South Africa [54].

\section{Strategies to Promote COVID-19 Vaccine Accessibility and Adoption}

\section{"Reimagining" COVID-19 Vaccine Doses to Improve Vaccine Accessibility}

One way to increase vaccine accessibility that many governments are considering is by giving as many people as possible one dose instead of the original and approved two-dose vaccination regimen for fewer people [55]. Britain, for instance, along with other European countries [56], has already delayed administering the scheduled second doses of COVID-19 vaccines on the ground that "vaccinating a greater number of people with a single dose will prevent more deaths and hospitalizations than vaccinating a smaller number with two doses" [55]. In addition to delaying the administration of the second vaccine dose and capitalizing on vaccine overfill (ie, some Pfizer-BioNTech vaccine vials were found to contain a greater amount of the vaccine dose than expected), a surprise that many health care professionals are happy to unveil [57], epidemiologists are also weighing in the option of cutting COVID-19 vaccine doses in half (ie, from $100 \mathrm{mg}$ to $50 \mathrm{mg}$ ), hoping to double the available Moderna vaccine supply in a timely fashion [58].

\section{"Extra" Doses or "Expected" Doses?}

Although all the abovementioned measures could help health experts and government officials to capitalize on available vaccine doses, they each come with their own sets of caveats. Among all three measures, the least problematic approach is probably leveraging the vaccine overfill issue. However, even this approach has issues. The first problem lies in the knowledge and experience needed to extract extra doses from the vaccine vials. COVID-19 vaccines are fancy magic delicately packaged in tiny glass vials - they are exceedingly expensive in the way they are designed, developed, delivered, and deployed with care, or lack thereof [11]. The vaccine extraction procedures require medical expertise and special equipment to succeed, which could be an issue considering that hospitals in worst-hit places are often stretched thin. The particular syringe needed for the procedure is in short supply [59]. The second issue is rooted in Pfizer-BioNTech's very business-minded calculations. Not wishing to break its Big Pharma stereotypes, Pfizer will deliver fewer numbers of vaccine vials to account for the difficult-to-extract "extra" doses-Pfizer's contractual agreement with the US government counts doses, rather than vials [60].

In other words, health care professionals in the United States may soon have to extract the "expected" doses from each Pfizer-BioNTech vaccine vial. It is important to incentivize businesses, especially powerful Big Pharmas, amid COVID-19 to contribute to social goods. However, particularly in light of mechanisms such as the Defense Production Act of 1950 [61], it is questionable whether financial incentives are the only approaches governments can use. When all members of the public have to follow the COVID-19 safety measures, such as the United Kingdom's waves of lockdowns, or get fined or jailed, for the greater good, then why are Big Pharma companies such as Pfizer-BioNTech not expected to do the same? Perhaps rather than arguing with governments about wording, dosing, and business bottom lines, Big Pharma companies like Pfizer-BioNTech should focus on producing more COVID-19 vaccines. Overall, it is not a sustainable approach to allow Big Pharma to see lucrative financial benefits in pandemics; societies at large have too many of these already for them to secure their astronomical bonus payments, ranging from the obesity epidemic, HIV epidemic, cancer epidemic, to communicable disease epidemics such as the annual seasonal influenza epidemics.

\section{Utilitarianism Without Consequentialism?}

For the approaches that disregard the originally and only clinically tested and approved sets of dosing guidelines, both the problems and solutions may be substantially more challenging to obtain. Essentially, the splitting doses (ie, getting more people to receive one dose of COVID-19 vaccine) and halving doses (ie, getting more people to receive at least some dose of COVID-19 vaccine) methods are a manifestation of "the greatest amount of good for the greatest number" utilitarian philosophy developed by famed scholars such as John Stuart Mill [62]. These approaches have the potential to allow more 
people to have access to COVID-19 vaccines without actually improving COVID-19 production rates; however, an important caveat is that there is a lack of data on what might be the health consequences of administering one or halved dose of COVID-19 vaccines, rather than the clinically validated dosing regimen. Data on Pfizer-BioNTech vaccines already shows that the high threshold efficacy for single dose of COVID-19 vaccine is $52 \%$. It could only reach the much-lauded $95 \%$ efficacy after the second dose is administered successfully within the prescribed time frame [63]. Available evidence from real-world mass vaccination in Israel further suggests that the actual efficacy of a single dose Pfizer-BioNTech vaccine may have a more disappointing number [64].

It is important to note that the statistics above only address the vaccine efficacy issue rather than other looming issues such as side effects and the interaction between coronavirus and vaccination. Some epidemiologists have already aired their concerns about the potential impacts of inoculating a large portion of the society with the same vaccine in a short time. Collectively, we have yet to figure out how coronavirus might evolve in light of these triggers; will a more potent and powerful variant of SARS-CoV-2 develop that is even more worrisome than the B.1.1.7 mutation first identified in the United Kingdom? It is important to note that some governments have already voiced their concerns over splitting and halving dosing COVID-19 vaccines. Even before data from Israel become available, making it the first country that has managed to vaccinate over $20 \%$ of its population and en route to inoculate the entire nation [65], the US Food and Drug Administration, for instance, warned public health officials of the danger associated with tempering with vaccine doses, citing that the idea is not supported by scientific evidence and "may ultimately be counterproductive to public health" [66].

A group of international advisers to the WHO, on the other hand, have recommended public health officials to follow the Pfizer-BioNTech vaccine schedule (ie, two doses given 3-4 weeks apart) rigorously when possible, but they have also suggested that countries with limited supplies of vaccines can consider delaying the second dose for up to 6 weeks [67]. It is important to note that initial evidence on dose splitting and extending intervals between shots is available from the AstraZeneca-Oxford trial [68]. Researchers found comparable efficacies between the two different time frames but disparate efficacies between dosages. Although these insights cannot be directly applied to mRNA vaccines developed by Pfizer-BioNtech and Moderna, they provide preliminary data on the interaction between dosing the vaccine efficacy, which should be further validated or updated by the mentioned effort undertaken by Moderna. Moreover, the Strategic Advisory Group of Experts on Immunization (SAGE), the committee that is tasked to advise WHO when it comes to immunization research and development (eg, COVID-19 vaccine guidelines) $[69,70]$, recommended WHO and all health officials to follow Pfizer-BioNTech dosing and timeframe scheme as the group was reporting the results of their discussion on the approval of the WHO's emergency use listing of Pfizer-BioNTech vaccines [71]. In extrapolation, then, it can be argued that it is recommended for officials to follow evidence-based schedules of the corresponding vaccines.

\section{Moral and Ethical Obligations in Public Health Policy-Making}

Overall, considering the tsunami of information-fact-based or not-on COVID-19 vaccines, data are urgently needed to shed light on the safety and practicality of changing previously agreed-upon vaccine dosing regimens. Promisingly, a group of scientists in the United States is currently collecting and analyzing data on Moderna vaccines to evaluate the possibility of halving COVID-19 vaccine doses to increase vaccine accessibility [72]. It is essential to digest the fact that devising a different dosing schedule is different from squeezing an additional dose from COVID-19 vaccine vials due to overfilling; the former changes the clinically tested and validated guidelines, whereas the latter simply capitalizes on the fact that some glass vials contain more amount of vaccine.

Although the exact impact of changing the COVID-19 vaccine dosing schedule on personal and public health amid the pandemic is still unclear, what is clear is that governments need to make sure they base their decisions on scientific evidence rather than hopeful assumptions [73]. Yet, baseless assumptions, let alone politics, influencing any decision about COVID-19 vaccines could potentially impact thousands of millions of people's lives and livelihoods. What is also clear is that, for people who have already received their first dose of COVID-19 vaccines, denying their access to the second dose is a blatant violation of informed consent, the very foundation of medical ethics, a baseline that should not be violated even in a time like the COVID-19 pandemic, particularly in light of dark events ranging from the Nazi's medical experiments [74], Unit 731 atrocities [75], and the Tuskegee scandal [76]. Obtaining informed consent from potential vaccine receivers has been a tricky task [11], and the violation of informed consent-a contractual trust between individuals and health organizations and governments - may further exacerbate vaccination hurdles for all other immunization efforts.

\section{Conclusions}

In this paper, we identified vaccine accessibility and adoption issues that can be collaboratively addressed by both private and public health sectors. Overall, more research is needed to shed light on these tasks, especially factoring in the ever-evolving nature of COVID-19 (eg, mutations) and phenomena such as "pandemic fatigue." Great hopes have been invested in COVID-19 vaccines. However, it is important to understand that, for COVID-19 vaccines to effectively protect people from the pandemic, issues such as vaccine accessibility, vaccine efficacy, and vaccine hesitancy need to be solved first. In the context of COVID-19, great hopes will almost always mean great expectations-health experts and government officials have a fiduciary and an unwavering duty to the public to make sure they promise what can be delivered and they deliver what is promised. Although even rays of hope can light up the tunnel, 
in an environment where distrust is rampant, hope could be easily lost and difficult to rebuild.

\section{Acknowledgments}

The authors wish to express their gratitude to the editor and reviewers for their constructive input and insightful feedback along with the kindness they showed to the team throughout the process. This work was supported by the Asia-Pacific Economic Cooperation (APEC) Funded Projects: Building the New Leadership of Infectious Disease Prevention and Control among APEC Economies and the United Nations Development Program (UNDP) South-South Cooperation: Learning from China's Experience to improve the Ability of Response to COVID-19 in Asia and the Pacific Region.

\section{Authors' Contributions}

ZS developed the research idea and drafted the manuscript. DMD, AC, XL, DM, SS, JA, and XH reviewed and revised the manuscript. All authors have read and approve the final manuscript.

\section{Conflicts of Interest}

None declared.

\section{References}

1. COVID-19 Dashboard by the Center for Systems Science and Engineering (CSSE) at Johns Hopkins University (JHU). Johns Hopkins Coronavirus Resource Center. URL: https://coronavirus.jhu.edu/map.html [accessed 2021-05-24]

2. The true death toll of COVID-19: Estimating global excess mortality. World Health Organization. URL: https://www. who.int/data/stories/the-true-death-toll-of-covid-19-estimating-global-excess-mortality [accessed 2021-05-24]

3. There have been $7 \mathrm{~m}-13 \mathrm{~m}$ excess deaths worldwide during the pandemic. The Economist. 2021 May 15. URL: https://www. economist.com/briefing/2021/05/15/there-have-been-7m-13m-excess-deaths-worldwide-during-the-pandemic [accessed 2021-05-24]

4. Burns D, John M. COVID-19 shook, rattled and rolled the global economy in 2020. Reuters. 2020 Dec 31. URL: https:/ /www.reuters.com/article/us-global-economy-yearend-graphic/ covid-19-shook-rattled-and-rolled-the-global-economy-in-2020-idUSKBN2950GH [accessed 2021-01-22]

5. Haas EJ, Angulo FJ, McLaughlin JM, Anis E, Singer SR, Khan F, et al. Impact and effectiveness of mRNA BNT162b2 vaccine against SARS-CoV-2 infections and COVID-19 cases, hospitalisations, and deaths following a nationwide vaccination campaign in Israel: an observational study using national surveillance data. The Lancet 2021 May;397(10287):1819-1829. [doi: 10.1016/s0140-6736(21)00947-8]

6. Thanh Le T, Andreadakis Z, Kumar A, Gómez Román R, Tollefsen S, Saville M, et al. The COVID-19 vaccine development landscape. Nat Rev Drug Discov 2020 May;19(5):305-306. [doi: 10.1038/d41573-020-00073-5] [Medline: 32273591]

7. Lurie N, Saville M, Hatchett R, Halton J. Developing Covid-19 vaccines at pandemic speed. N Engl J Med 2020 May 21;382(21):1969-1973. [doi: 10.1056/nejmp2005630]

8. Timeline: WHO's COVID-19 response. World Health Organization. Timeline URL: https://www.who.int/emergencies/ diseases/novel-coronavirus-2019/interactive-timeline [accessed 2021-05-24]

9. Baraniuk C. Covid-19: How the UK vaccine rollout delivered success, so far. BMJ 2021 Feb 18;372:n421. [doi: 10.1136/bmj.n421] [Medline: $\underline{3602672]}$

10. Restaurants and pubs are reopening inside, but what are the rules? BBC News. 2021 May 21. URL: https://www.bbc.com/ news/business-52977388 [accessed 2021-05-24]

11. Su Z, Wen J, McDonnell D, Goh E, Li X, Šegalo S, et al. Vaccines are not yet a silver bullet: The imperative of continued communication about the importance of COVID-19 safety measures. Brain Behav Immun Health 2021 Mar;12:100204 [FREE Full text] [doi: 10.1016/j.bbih.2021.100204] [Medline: 33495754]

12. Su Z, Wen J, Abbas J, McDonnell D, Cheshmehzangi A, Li X, et al. A race for a better understanding of COVID-19 vaccine non-adopters. Brain Behav Immun Health 2020 Dec;9:100159 [FREE Full text] [doi: 10.1016/j.bbih.2020.100159] [Medline: 33052327]

13. Callaway E. Fast-spreading COVID variant can elude immune responses. Nature 2021 Jan;589(7843):500-501. [doi: 10.1038/d41586-021-00121-z] [Medline: 33479534]

14. Freeman D, Loe BS, Chadwick A, Vaccari C, Waite F, Rosebrock L, et al. COVID-19 vaccine hesitancy in the UK: the Oxford coronavirus explanations, attitudes, and narratives survey (Oceans) II. Psychol Med 2020 Dec 11:1-15 [FREE Full text] [doi: 10.1017/S0033291720005188] [Medline: 33305716]

15. Gabrielson R, Chen C, Simon M. How Many Vaccine Shots Go to Waste? Several States Aren't Counting. ProPublica. 2021 Jan. URL: https://www.propublica.org/article/covid-vaccine-wastage [accessed 2021-01-22]

16. Smout A. In COVID-19 milestone for West, Britain starts mass vaccination. Reuters. 2020 Dec 7. URL: https://www. reuters.com/article/us-health-coronavirus-britain-vaccine-idUSKBN28I01T [accessed 2020-12-09] 
17. COVID-19 Vaccination Program Jurisdiction Operations. Centers for Disease Control and Prevention. 2020 Oct 29. URL: https://www.cdc.gov/vaccines/imz-managers/downloads/COVID-19-Vaccination-Program-Interim Playbook.pdf [accessed 2020-12-09]

18. Khalil A, Kalafat E, Benlioglu C, O'Brien P, Morris E, Draycott T, et al. SARS-CoV-2 infection in pregnancy: A systematic review and meta-analysis of clinical features and pregnancy outcomes. EClinicalMedicine 2020 Aug;25:100446 [FREE Full text] [doi: 10.1016/j.eclinm.2020.100446] [Medline: 32838230]

19. Honderich H. Will pregnant women receive the Covid-19 vaccine? It depends. BBC News. 2020 Dec 22. URL: https:/ /www.bbc.com/news/world-us-canada-55340244 [accessed 2020-12-24]

20. Vitale C, Fini M, Spoletini I, Lainscak M, Seferovic P, Rosano GM. Under-representation of elderly and women in clinical trials. Int J Cardiol 2017 May 01;232:216-221. [doi: 10.1016/j.ijcard.2017.01.018] [Medline: 28111054]

21. Rich countries hoarding Covid vaccines, says People's Vaccine Alliance. BBC News. 2020 Dec 9. URL: https://www. bbc.co.uk/news/health-55229894 [accessed 2020-12-09]

22. Dyer O. Covid-19: Many poor countries will see almost no vaccine next year, aid groups warn. BMJ 2020 Dec 11;371:m4809. [doi: 10.1136/bmj.m4809] [Medline: $\underline{33310819}$ ]

23. Interactive COVAX Map. Launch \& Scale Speedometer. Durham, NC: Duke Global Health Innovation Center, Duke University URL: https://launchandscalefaster.org/COVID-19 [accessed 2021-01-06]

24. Doucleff M. How rich countries are 'hoarding' the world's vaccines, in charts. NPR. 2020 Dec 3. URL: https://www.npr.org/ sections/goatsandsoda/2020/12/03/942303736/

how-rich-countries-are-hoarding-the-worlds-vaccines-in-charts? $\mathrm{t}=1607496526830$ [accessed 2020-12-09]

25. COVID-19 vaccines. World Health Organization. URL: https://www.who.int/emergencies/diseases/novel-coronavirus-2019/ covid-19-vaccines [accessed 2020-12-24]

26. Pfizer-BioNTech COVID-19 vaccine. Centers for Disease Control and Prevention - Vaccines and Immunization. URL: https://www.cdc.gov/vaccines/covid-19/info-by-product/pfizer/index.html [accessed 2020-12-24]

27. Checklist for storage, handling, and preparation of the Pfizer-BioNTech COVID-19 Vaccine. Pfizer-BioNTech. 2020. URL: https://www.cvdvaccine-us.com/images/pdf/Checklist.pdf [accessed 2020-12-24]

28. Developing and delivering covid-19 vaccines around the world. World Trade Organization. URL: https://www.wto.org/ english/tratop e/covid19 e/vaccine report e.pdf [accessed 2020-12-24]

29. Wright W. A company vaccinating Ohio nursing-home residents lets 890 doses go bad. The New York Times. 2021 Feb 1. URL: https://www.nytimes.com/live/2021/01/20/world/covid-19-coronavirus/ a-company-vaccinating-ohio-nursing-home-residents-lets-890-doses-go-bad [accessed 2021-05-31]

30. UNICEF to stockpile over half a billion syringes by year end, as part of efforts to prepare for eventual COVID-19 vaccinations. United Nations International Children's Emergency Fund. 2020 Oct 19. URL: https://www.unicef.org/press-releases/ unicef-stockpile-over-half-billion-syringes-year-end-part-efforts-prepare-eventual [accessed 2020-12-09]

31. COVID-19 vaccination: Governance, handling and preparation of vaccines in Hospital Hubs and Vaccination Centres. National Health Service. 2020 Dec 4. URL: https://www.england.nhs.uk/coronavirus/wp-content/uploads/sites/52/2020/ 12/C0926-COVID-19-vaccination-Governance-handling-and-preparation-of-vaccines-in-Hospital-Hubs-and-Vaccination-Ce. pdf [accessed 2020-12-09]

32. Wolfe L. 42 people in West Virginia are mistakenly given a virus treatment instead of the vaccine. The New York Times. 2020 Dec 31. URL: https://www.nytimes.com/2020/12/31/us/west-virginia-covid-vaccine-regeneron.html [accessed 2021-01-06]

33. Bernstein S. No intensive care beds for most Californians as COVID-19 surges. Reuters. 2020 Dec 21. URL: https://www. reuters.com/article/us-health-coronavirus-usa-california/ no-intensive-care-beds-for-most-californians-as-covid-19-surges-idUSKBN28V2R6 [accessed 2021-01-22]

34. Covid-19: Brazil hospitals 'run out of oxygen' for virus patients. BBC News. 2021 Jan 15. URL: https://www.bbc.com/ news/world-latin-america-55670318 [accessed 2021-01-22]

35. Ranzani OT, Bastos LSL, Gelli JGM, Marchesi JF, Baião F, Hamacher S, et al. Characterisation of the first 250000 hospital admissions for COVID-19 in Brazil: a retrospective analysis of nationwide data. The Lancet Respiratory Medicine 2021 Apr;9(4):407-418. [doi: 10.1016/s2213-2600(20)30560-9]

36. El-Naggar M, Al-Hlou Y. Egypt denied an oxygen failure killed COVID patients. We found that it did. The New York Times. 2021 Jan 18. URL: https://www.nytimes.com/2021/01/18/world/middleeast/egypt-hospital-oxygen-covid.html [accessed 2021-01-22]

37. Triggle N, Schraer R. Covid-19 vaccine: Allergy warning over new jab. BBC News. 2020 Dec 9. URL: https://www. bbc.com/news/health-55244122 [accessed 2020-12-24]

38. Wise J. Covid-19: European countries suspend use of Oxford-AstraZeneca vaccine after reports of blood clots. BMJ 2021 Mar 11;372:n699. [doi: 10.1136/bmj.n699] [Medline: 33707182]

39. Klimek L, Novak N, Hamelmann E, Werfel T, Wagenmann M, Taube C, et al. Severe allergic reactions after COVID-19 vaccination with the Pfizer/BioNTech vaccine in Great Britain and USA. Allergo J Int 2021;30(2):51-55 [FREE Full text] [doi: 10.1007/s40629-020-00160-4] [Medline: 33643776] 
40. CDC COVID-19 Response Team, FoodDrug Administration. Allergic Reactions Including Anaphylaxis After Receipt of the First Dose of Moderna COVID-19 Vaccine - United States, December 21, 2020-January 10, 2021. MMWR Morb Mortal Wkly Rep 2021 Jan 29;70(4):125-129 [FREE Full text] [doi: 10.15585/mmwr.mm7004e1] [Medline: 33507892]

41. Cirillo N. Reported orofacial adverse effects of COVID-19 vaccines: The knowns and the unknowns. J Oral Pathol Med 2021 May;50(4):424-427 [FREE Full text] [doi: 10.1111/jop.13165] [Medline: 33527524]

42. Interim clinical considerations for use of mRNA COVID-19 vaccines currently authorized in the United States. Centers for Disease Control and Prevention. URL: https://www.cdc.gov/vaccines/covid-19/info-by-product/clinical-considerations. $\underline{\mathrm{html}}$ [accessed 2021-01-06]

43. McNeil MM, DeStefano F. Vaccine-associated hypersensitivity. J Allergy Clin Immunol 2018 Feb;141(2):463-472 [FREE Full text] [doi: 10.1016/j.jaci.2017.12.971] [Medline: 29413255]

44. CDC COVID-19 Response Team, FoodDrug Administration. Allergic reactions including anaphylaxis after receipt of the first dose of Pfizer-BioNTech COVID-19 vaccine - United States, December 14-23, 2020. MMWR Morb Mortal Wkly Rep 2021 Jan 15;70(2):46-51 [FREE Full text] [doi: 10.15585/mmwr.mm7002e1] [Medline: 33444297]

45. Torjesen I. Covid-19: Norway investigates 23 deaths in frail elderly patients after vaccination. BMJ 2021 Jan 15;372:n149. [doi: 10.1136/bmj.n149] [Medline: 33451975$]$

46. Szabo L. Anti-vaccine activists peddle theories that COVID shots are deadly, undermining vaccination. Kaiser Family Foundation. 2021 Jan 25. URL: https://khn.org/news/article/ anti-vaccine-activists-peddle-theories-that-covid-shots-are-deadly-undermining-vaccination/ [accessed 2021-01-26]

47. Teixeira da Silva J. Corona exhaustion (CORONEX): COVID-19-induced exhaustion grinding down humanity. Current Research in Behavioral Sciences 2021 Nov;2:100014 [FREE Full text] [doi: 10.1016/j.crbeha.2021.100014]

48. Reicher S, Drury J. Pandemic fatigue? How adherence to covid-19 regulations has been misrepresented and why it matters. BMJ 2021 Jan 18;372:n137. [doi: 10.1136/bmj.n137] [Medline: 33461963]

49. Su Z, McDonnell D, Wen J, Kozak M, Abbas J, Šegalo S, et al. Mental health consequences of COVID-19 media coverage: the need for effective crisis communication practices. Global Health 2021 Jan 05;17(1):4 [FREE Full text] [doi: 10.1186/s12992-020-00654-4] [Medline: 33402169]

50. Paltiel AD, Schwartz JL, Zheng A, Walensky RP. Clinical outcomes of a COVID-19 vaccine: Implementation over efficacy. Health Aff (Millwood) 2021 Jan;40(1):42-52. [doi: 10.1377/hlthaff.2020.02054] [Medline: 33211536]

51. de Figueiredo A, Simas C, Karafillakis E, Paterson P, Larson HJ. Mapping global trends in vaccine confidence and investigating barriers to vaccine uptake: a large-scale retrospective temporal modelling study. The Lancet 2020 Sep;396(10255):898-908. [doi: 10.1016/s0140-6736(20)31558-0]

52. COCONEL Group. A future vaccination campaign against COVID-19 at risk of vaccine hesitancy and politicisation. Lancet Infect Dis 2020 Jul;20(7):769-770 [FREE Full text] [doi: 10.1016/S1473-3099(20)30426-6] [Medline: 32445713]

53. Detoc M, Bruel S, Frappe P, Tardy B, Botelho-Nevers E, Gagneux-Brunon A. Intention to participate in a COVID-19 vaccine clinical trial and to get vaccinated against COVID-19 in France during the pandemic. Vaccine 2020 Oct 21;38(45):7002-7006 [FREE Full text] [doi: 10.1016/j.vaccine.2020.09.041] [Medline: $\underline{32988688}$ ]

54. Loftus P. Wall Street Journal. 2021 Jan 29. URL: https://www.wsj.com/articles/ j-j-covid-19-vaccine-was-66-effective-in-late-stage-study-11611925201?mod=djemalertNEWS [accessed 2021-01-29]

55. McKie R. Why is Britain delaying second doses of Covid vaccines? The Guardian. 2021 Jan 3. URL: https://www. theguardian.com/world/2021/jan/03/why-britain-delaying-second-doses-covid-19-vaccines [accessed 2021-05-31]

56. Wu K, Robbins R. In Europe, more countries delay second vaccine doses or mull plans to do so. The New York Times.: New York Times; 2021 Jan 4. URL: https://www.nytimes.com/2021/01/04/world/second-covid-vaccine-delay.html [accessed 2021-01-06]

57. Thomas K. Hospitals Discover a Surprise in Their Vaccine Deliveries: Extra Doses. The New York Times. 2020 Dec 16. URL: https://www.nytimes.com/2020/12/16/health/Covid-Pfizer-vaccine-extra-doses.html [accessed 2021-01-06]

58. Pierson B. U.S. may cut some Moderna vaccine doses in half to speed rollout, official says. Reuters. 2021 Jan 3. URL: https://www.reuters.com/article/us-health-coronavirus-usa-moderna/

u-s-may-cut-some-moderna-vaccine-doses-in-half-to-speed-rollout-official-says-idUSKBN2980NW [accessed 2021-01-06]

59. Rowland C. Biden wants to squeeze an extra shot of vaccine out of every Pfizer vial. It won't be easy. The Washington Post. 2021 Jan 22. URL: https://www.washingtonpost.com/business/2021/01/22/pfizer-vaccine-doses-syringes/ [accessed 2021-01-24]

60. Weiland N, Thomas K, LaFraniere S. Pfizer will ship fewer vaccine vials to account for extra doses. The New York Times. 2021 Jan 22. URL: https://www.nytimes.com/2021/01/22/health/pfizer-vaccine.html [accessed 2021-01-23]

61. Defense Production Act. FEMA - U.S. Department of Homeland Security. URL: https://www.fema.gov/disasters/ defense-production-act [accessed 2021-01-24]

62. Mill JS. Utilitarianism. London: Longmans, Green and Company; 1879. URL: https://www.worldcat.org/title/utilitarianism/ oclc/5321953 [accessed 2021-05-31]

63. Mahase E. Covid-19: Pfizer vaccine efficacy was 52\% after first dose and $95 \%$ after second dose, paper shows. BMJ 2020 Dec 11;371:m4826. [doi: 10.1136/bmj.m4826] [Medline: 33310706] 
64. Mahase E. Covid-19: Reports from Israel suggest one dose of Pfizer vaccine could be less effective than expected. BMJ 2021 Jan 22;372:n217. [doi: 10.1136/bmj.n217] [Medline: 33483332]

65. Zion IB. Israel trades Pfizer doses for medical data in vaccine blitz. Associated Press. 2021 Jan 18. URL: https://apnews. com/article/ international-news-israel-coronavirus-vaccine-coronavirus-pandemic-benjamin-netanyahu-b30f9af2139e64794ce66c6c9b367b7b [accessed 2021-01-24]

66. FDA statement on following the authorized dosing schedules for covid-19 vaccines. U.S. Food and Drug Administration. 2021 Jan 4. URL: https://tinyurl.com/3cz3sx7x [accessed 2021-01-06]

67. Media briefing on COVID-19. YouTube.: World Health Organization; 2021 Jan 5. URL: https://www.youtube.com/ watch?v=57S_hkmUpHw\&feature=emb_title [accessed 2021-01-06]

68. Folegatti PM, Ewer KJ, Aley PK, Angus B, Becker S, Belij-Rammerstorfer S, Oxford COVID Vaccine Trial Group. Safety and immunogenicity of the ChAdOx1 $\mathrm{nCoV}-19$ vaccine against SARS-CoV-2: a preliminary report of a phase 1/2, single-blind, randomised controlled trial. Lancet 2020 Aug 15;396(10249):467-478 [FREE Full text] [doi: 10.1016/S0140-6736(20)31604-4] [Medline: 32702298]

69. Strategic Advisory Group of Experts on Immunization (SAGE). World Health Organization. URL: https://www.who.int/ groups/strategic-advisory-group-of-experts-on-immunization [accessed 2021-01-21]

70. SAGE Working Group on Covid-19 vaccines (established June 2020). World Health Organization. URL: https://www. who.int/immunization/sage/sage wg covid-19/en/ [accessed 2021-01-21]

71. Farge E, Revill J. WHO recommends two doses of Pfizer COVID-19 vaccine within 21-28 days. Reuters. 2021. URL: https://www.reuters.com/article/us-health-coronavirus-who/ who-recommends-two-doses-of-pfizer-covid-19-vaccine-within-21-28-days-idUSKBN29A25G [accessed 2021-01-21]

72. Stolberg S, LaFraniere S. Warning of shortages, researchers look to stretch vaccine supply. The New York Times. 2021 Jan 5. URL: https://www.nytimes.com/2021/01/05/us/politics/coronavirus-vaccine-supply.html [accessed 2021-01-06]

73. Su Z, McDonnell D, Ahmad J. The need for a disaster readiness mindset: A key lesson from the coronavirus disease 2019 (COVID-19) pandemic. Infect Control Hosp Epidemiol 2021 Jan 25:1-2 [FREE Full text] [doi: 10.1017/ice.2021.26] [Medline: $\underline{33487209}$ ]

74. Mellanby K. Medical experiments on human beings in concentration camps in Nazi Germany. Br Med J 1947 Jan 25;1(4490):148-150 [FREE Full text] [doi: 10.1136/bmj.1.4490.148] [Medline: 20244692]

75. Su Z, McDonnell D, Cheshmehzangi A, Abbas J, Li X, Cai Y. The promise and perils of Unit 731 data to advance COVID-19 research. BMJ Glob Health 2021 May 20;6(5):e004772 [FREE Full text] [doi: 10.1136/bmjgh-2020-004772] [Medline: 34016575]

76. The Tuskegee timeline. Centers for Disease Control and Prevention. URL: https://www.cdc.gov/tuskegee/timeline.htm [accessed 2021-01-21]

\section{Abbreviations}

EU: European Union

SAGE: Strategic Advisory Group of Experts on Immunization

WHO: World Health Organization

Edited by T Sanchez; submitted 27.11.20; peer-reviewed by LT Sen, M Das, F Jijrees; comments to author 23.12.20; revised version
received 24.12.20; accepted 01.02.21; published 04.08.21
Please cite as:
Su Z, McDonnell D, Cheshmehzangi A, Li X, Maestro D, Šegalo S, Ahmad J, Hao X
With Great Hopes Come Great Expectations: Access and Adoption Issues Associated With COVID-19 Vaccines
JMIR Public Health Surveill 2021;7(8):e26111
URL: $\underline{\text { https://publichealth.jmir.org/2021/8/e26111 }}$
doi: $\underline{10.2196 / 26111}$
PMID: $\underline{3560997}$

(CZhaohui Su, Dean McDonnell, Ali Cheshmehzangi, Xiaoshan Li, Daniel Maestro, Sabina Šegalo, Junaid Ahmad, Xiaoning Hao. Originally published in JMIR Public Health and Surveillance (https://publichealth.jmir.org), 04.08.2021. This is an open-access article distributed under the terms of the Creative Commons Attribution License (https://creativecommons.org/licenses/by/4.0/), which permits unrestricted use, distribution, and reproduction in any medium, provided the original work, first published in JMIR Public Health and Surveillance, is properly cited. The complete bibliographic information, a link to the original publication on https://publichealth.jmir.org, as well as this copyright and license information must be included. 